\title{
Olympic Legacy
}

The field of architecture has tended to remember the spaces of recent Olympic games in terms of individual canonical buildings. Think, for example, of Frei Otto and Gunter Behnisch's stadium built in Munich for the 1972 games which tested the possibilities of tensile structures, or the spectacular image of Herzog and de Meuron's Birds' Nest stadium as constructed in Beijing in 2008. While it is too soon to tell, London's 2012 Olympics may have also contributed objects to the architectural canon: Zaha Hadid Architects' striking Aquatics Centre, perhaps, as recently shorn of its temporary wings or, more quietly, Hopkins' Architects effective and economical velodrome. But such a limited view, favouring Olympic architectural trophies, is to neglect the broader possibilities for employing Games expenditure in service of urban regeneration.

The Barcelona Olympics of 1992 demonstrated this potential. The new Port Olimpic district was reclaimed from industrial tips, burying urban obstacles such as railway lines to connect the city more strongly to the sea. Both the example of Barcelona and the inflated language necessitated by the bidding process for the Games have resulted in numerous bold claims about the transformative potential of Olympic legacy for communities, for architecture and urban design. Specifically in relation to London 2012, the rhetoric of the bid - like that of the Olympic Delivery Authority, the UK public body set up to administer the Games infrastructure - seems to demand scrutiny in the cool light of day, to test outcomes against promises. Two years on from London 2012, while the dust on numerous construction sites continues to settle both literally and metaphorically, it is too soon for any final accounting. Nevertheless, now seems like a good time to begin taking stock.

This issue of arq, curated on the initiative of Juliet Davis of Cardiff University, aims to bring together a set of critical perspectives on London's Olympic legacy, paying special attention to Stratford and the Lea Valley, the main site of the Games. Davis' introductory 'perspective' (pp. 299-301) establishes the context for the papers included here. They deal with: portrayals of the Olympic site (William Mann's paper, pp. 302-314, and Oliver Froome Lewis on 'Lea Valley Drift', pp. 377-388); the promises articulated to people and places (Andrew Smith on the re-framing of the idea of a park, pp. 315-323, and Graeme Evans writing about a 'hands on cultural framework', pp. 353-366); and questions of the future (Andrew Hoolachan on sustainability, pp. 342-351, and Issac Marrero-Guillamón on temporary urbanism, pp. 367-376). As Davis reflects, the papers deal with 'relationships between designed outcomes and legacy governance', 'modes of looking and seeing' and 'questions of time [and] stories of urban change'. Many of those stories are still in flux with respect to London but we hope this issue of arq will make an important contribution to the study of Olympic legacy, both internationally and with respect to London 2012.

THE EDITORS 


\section{architectural research quarterly}

\section{Subscribe now for 2015}

Innovative in conception, unique in breadth and generously illustrated, this pace-setting quarterly publication from Cambridge University Press links, on a global scale, the worlds of architectural practice and research. arq regularly includes extensive peer-reviewed sections on design, history, theory, construction, environmental design, education and practice - as well as structures, urbanism and documents. These are supplemented by letters, reports, reviews and an annual index. Each issue opens with a leader and closes with insight, a personal end-piece. In its eighteen year history, arq has published work from all over the world: from Chile to Sweden and from Japan to the Netherlands - with a strong representation from the United Kingdom and United States. arq, like architecture itself, is all-embracing and written by and for both practitioners and academics. It provides an outlet for all those who wish to disseminate their work to an international audience.

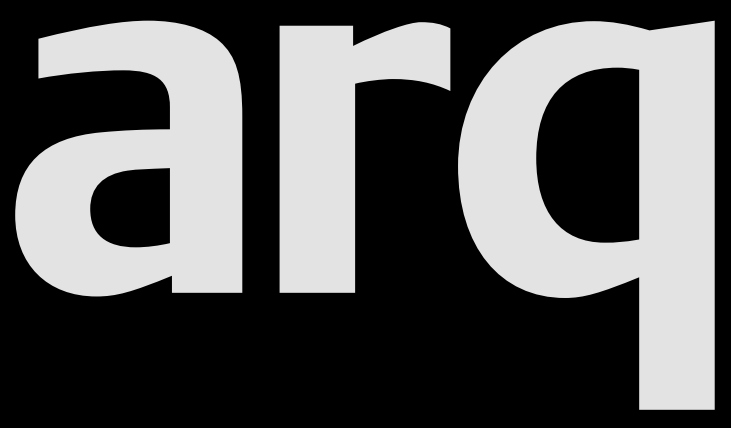

Please enter my subscription to arq: architectural research quarterly, volume 19, 2015

$\square$ £257/\$432 institutions print and electronic E34/\$57 students print only

$\ldots £_{50} / \$ 77$ individuals print only

EU residents only. VAT may be payable at your local rate if not registered.

Our VAT registration number: GB 214141614 If registered, your VAT registration no:

Total subscription payment $€ / \$$ EU residents only, if not registered add VAT at appropriate rate

Canadian residents, add 7\% GST \$

Total $\mathbf{E} / \mathbf{S}$

Name

Address

\section{Payment enclosed}

Cheque in sterling or US dollars

(payable to Cambridge University Press)

Credit Card - VISA | MasterCard | American Express (delete where applicable)

Card no

Expiry date

Signature

Photocopy this page and send your order to: Journals Customer Services, Cambridge University Press, UPH, Shaftesbury Road, Cambridge, С 2 8B , UK
$\mathrm{T}+44(0) 1223326070$
$\mathrm{F}+44(0) 1223315052$
E journals@cambridge.org
or in USA, Canada and Mexico send to:
Cambridge University Press, 32 Avenue of the
Americas, New York NY 10013-2473, USA
T (914) 9379600
F (914) 9374712
E journals_subscriptions@cup.org 